This item was submitted to Loughborough's Research Repository by the author.

Items in Figshare are protected by copyright, with all rights reserved, unless otherwise indicated.

\title{
The SERVICE framework: a public-service-dominant approach to sustainable public services
}

PLEASE CITE THE PUBLISHED VERSION

http://dx.doi.org/10.1111/1467-8551.12094

\section{PUBLISHER}

Wiley / @ British Academy of Management

VERSION

AM (Accepted Manuscript)

\section{PUBLISHER STATEMENT}

This work is made available according to the conditions of the Creative Commons Attribution-NonCommercialNoDerivatives 4.0 International (CC BY-NC-ND 4.0) licence. Full details of this licence are available at: https://creativecommons.org/licenses/by-nc-nd/4.0/

\section{LICENCE}

CC BY-NC-ND 4.0

\section{REPOSITORY RECORD}

Osborne, Stephen P., Zoe J. Radnor, Tony Kinder, and Isabel Vidal. 2019. "The SERVICE Framework: A Public-service-dominant Approach to Sustainable Public Services". figshare. https://hdl.handle.net/2134/19047. 


\section{The SERVICE framework: a public service-dominant approach to sustainable public services}

Building upon the call of Ashworth et al (2013) for more theoretical critique and development of public management theory, the central argument of this paper is that the premises that underlie much contemporary public management theory, in its guise as the New Public Management (NPM), are flawed and have led to variable results in implementation. Far from creating the basis for sustainable public service organisations (PSOs) this body of theory has actually undermined their sustainability by encouraging a short term, introspective and transactional approach to the delivery of public services (Radnor \& Barnes 2007, McLaughlin et al 2009). We offer an alternative to this, based within the public service-dominant framework for public services delivery (Osborne et al 2013). We argue that it is essential for PSOs to move beyond the transactional approach and take a relational and public servicedominant approach that emphasises three elements: building relationships across the public service delivery system; understanding that sustainability derives from the transformation of user knowledge and; professional understanding of the public service delivery process which is predicated upon the inalienable co-production with service users.

Consequently this paper is in three parts. The first part develops a critique of the NPM and poses the 'New Public Governance' (NPG) as an alternative to it. The second part of the paper then offers a framework for the creation of sustainable business models for a whole range of PSOs - the SERVICE framework. The final part of the paper highlights its contribution and implications for theory and practice. Further, because this paper is a conceptual and theoretical one, the research agenda at the end of this paper details the research needed in the future to empirically test, validate and develop the framework proposed.

We would emphasise that in proposing this framework, we are not creating it from first principles. On the contrary, It is draws upon and is embedded within am emerging strand of public management research and theory from over the last 
decade, and more (for example, Klijn 2008, Gains \& Stoker 2009, Guthrie et al 2010, Benington \& Moore 2010, Dahler-Larsen 2014). What our framework does is to build upon these insights and to develop an integrated context within which to entrench sustainable business practice for PSOs over the next decade, and beyond.

\section{From NPM to the NPG}

Elsewhere we have charted the development of the New Public Management as a response to the perceived failings of Public Administration and the subsequent challenge to its shortcomings from the New Public Governance (XXXXX 2013, 2014). Others have also indicated that the NPM was not solely a managerialist movement to reform public services but also an ideological attempt to 'roll back the state' and to reconfigure the post-war European consensus on the welfare state (Dawson \& Dargie 1999). A final line of argument has posed NPM as an aberrant departure from the accountability concerns of 'traditional' public administration across Europe and called for the latter's re-invigoration (Kickert 1997).

In this paper, we focus on what we argue are the shortcomings of the NPM that derive from five directions. First, society has been transformed profoundly since the early inception of the NPM in the 1980s. Society has become more fragmented and the processes of public service delivery have diversified - a phenomenon referred to elsewhere as the 'hollowing out of the state' (Rhodes 1994, Haveri 2007, Milward \& Provan 2000,). Consequently PSOs can no longer act as if their efficiency, effectiveness and sustainability are in their own hands alone. In reality PSOs are now part of complex public service delivery systems where their mission-critical objectives require the successful negotiation of relationships within these systems with policy makers, other PSOs, service users, citizens, and indeed a range of service system elements and stakeholders. This is discussed further below.

Significantly the NPG perspective goes beyond the network governance approach that has been articulated by, amongst others, Klijn (2008). These latter approaches acknowledge that individual PSOs can no longer act in isolation and that they require a focus upon inter-organisational policy and implementation networks (comprising a 
multiplicity of PSOs) to properly understand the delivery of public services. However, the thrust of the NPG is that such an inter-organisational perspective is necessary but not sufficient. Drawing upon services theory (e.g. Gronroos 2007) it conceptualises public services not as produced within inter-organisational networks alone but rather as produced within public service systems, as suggested above. It is the interaction of these complex service systems that is the core to effective public service delivery not simply the governance of networks of PSOs (Chen et al 2014). The task is thus not simply the governance of networks of PSOs but the operationalization of these interactive and complex service systems.

Second, the NPG paradigm argues that PSOs are not producing technically designed and manufactured products - but rather are delivering intangible services that require attention to the processes of service delivery and to relationships with service users, and not simply to service design. Gronroos (1998) has identified this search for the 'missing product' as a common mistake of failing service firms and this is equally relevant to PSOs as they strive to develop sustainable business models for the twenty first century.

Third, PSOs also need to recognise that the short-termism and product-dominant basis of the NPM is counter-productive to their survival. It assumes that their sustainability is driven by a business equation where production and consumption are treated separately - the costs of the former can be reduced without affecting the latter. This might be the case for manufactured products, but it is certainly not the case for services, including public services. In this case reducing production costs directly affects the quality of their use/consumption - and this affects their longer term viability and sustainability (Normann 2000, Gronroos \& Ojasalo 2004). A key issue here is the role of staff in service delivery. For many service firms they are one of their most expensive costs. PSOs, in particular, have sought to limit unit costs by reducing staff costs (such as residential homes for elderly people employing less well trained staff or reducing staffing ratios). Service theory identifies this as a potentially counter-productive approach. Reducing staff costs without consideration of the delivery process can reduce the quality of the service - and which ultimately 
undermines their sustainability in a mixed economy of care. Rather, service firms need to invest in the 'right' staffing to ensure and improve the quality of the service delivered, thus strengthening their market position and sustainability - what Normann (2000) calls the 'virtuous circle' for the profitability and sustainability of service firms.

Fourth, throughout both public administration and the NPM, the task of public service delivery has been conceptualised as something to be enacted by public service professionals and where the service user is largely passive in the process, whether considered as a 'client' or 'customer' of PSOs. There have of course been movements to bring the service user into a more active role in service delivery through 'co-production' (an excellent summary of this literature is provided by Alford 2014). Important as these approaches are, though, they frequently mistake the nature of public service delivery. In reality it is impossible to deliver any service without an element of co-production (Xue \& Harker 2003). Co-production is part of the very essence of a service both because its performance is created where the user's expectations collide with their experience of the service and because the user themselves is an active part of the service process not a passive recipient of its outputs. Consequently the task becomes not one of how to bring the user into coproduction but rather how to engage actively with this already existing co-production within the public service delivery process in order both to improve the quality of existing services and to plan for future service delivery and innovation. It is important to be clear that this is different from the 'consumerist' movement that has dogged public services over recent decades. This movement sought to extract and objectify the 'public service consumer' from the overall service process and has been subject to strong critiques elsewhere (e.g. Powell et al 2010). What is proposed here is rather to understand the totality of the public service production system and the complex iterative interactions between services users and public service staff that occur within it.

Finally, the NPM appears limited in its response to the challenges to traditional public services delivery of knowledge-driven services delivery within the digital economy. 
Not only is this latter phenomenon transforming the nature of relationships between PSOs, politicians and service users, it is posing questions about the achievement of public value as the indicator of public service effectiveness rather than internal measures of public service efficiency (e.g. Moore 2002, Bekkers et al 2011, Benington \& Moore 2010) and the governance processes required to negotiate agreement about such effectiveness (e.g. Brown \& Osborne 2013). The debate about public value is an important one. It shifts the focus of reforming public services away from internal efficiency alone and situates it rather within the context of adding value to the lives of citizens and service users - whilst also acknowledging that such 'value' is negotiated within the democratic polity (Gains \& Stoker 2009). The concept of public value is returned to further below.

This is not to say that the NPM has had no positive impacts upon public services delivery. This would be facile. As we argue below it has been significant in addressing the prior poor design of public services in many countries (Barraza et al 2009, Radnor 2010), it has revealed the importance of balancing efficiency and effectiveness in delivery public services and provided important tools to do so (Hogstrom et al 2014, Dahler-Larsen 2014. Also the use of contractual mechanisms within a NPM framework has sharpened the focus of service delivery in many cases (Wistow et al 1994). Some have also argued that it has been an important tool of reform to drive broader societal reform in central and eastern Europe (Sorin \& Pollitt 2015). However our argument is that, valuable as these benefits have been, their impact has been diminished by the flaws of NPM in practice as discussed above and particularly by the extent to which it has produced an introspective and shortterm culture and strategic orientation that has diminished the ability of PSOs both to respond to external change and to deliver external effectiveness and public value.

Interim conclusion. What has been remarkable in the early responses to the global recession by governments and PSOs alike is how rooted they have been in the tenets of the 'old' NPM and the belief that internal cost cutting and efficiency programmes will produce sustainable PSOs for the long term (or even the middle term, for that matter) - despite the limitations outlined above. The underlying 
question therefore is that of the nature of sustainable business practice for PSOs within this new reality. In the next part of this paper we will sketch the elements of an alternative framework of sustainable business practice for PSOs that embraces both the reality of the challenges that the NPG paradigm poses for them and the implications of a public service-dominant logic for public services delivery.

\section{Towards a framework for sustainable business models for PSOs:}

Sustainable business practice in commercial markets has traditionally been equated with a healthy 'bottom line' profitability that provides a return for share-holders and/or owners (Farris et al 2010). More recently however, there has also been a growing awareness that, even in commercial markets, this is not sufficient. This has led to alternative models of sustainable practice including the triple bottom line (Elkington 1994) and social audit and social accounting based ones (Gray 2002).

For PSOs, there has been a strong critical accounting strand over the past twenty years that has argued that 'traditional' bottom line measures of sustainability capture neither the complexity of the challenges that PSOs face, as outline above (Stoker 2006, Benington \& Moore 2010), nor their role in contributing to higher level goals of sustainable economies and societies (Ball \& Osborne 2010, Guthrie et al 2010). Osborne (2010) posed the question as to what constitutes sustainability for PSOs within the NPG. Drawing upon the above we would argue that it is insufficient to define this as the sustainability of individual PSOs. This is of course essential to ensure that there are individual providers of PSOs. However the sustainability of individual PSOs has to be integrated both with an outward-facing concern with public service effectiveness (Radnor \& Osborne 2013), the creation of public value (Moore 2002), and a balancing of individual organisational sustainability against overall service sustainability (Radnor et al 2014). Consequently we would argue that sustainability for PSOs must be assessed across four dimensions:

- The sustainability of individual PSOs,

- The sustainability of public service delivery systems and their governance mechanisms,

- The sustainability of local communities, and 
- Environmental sustainability.

This necessitates PSOs moving beyond strategic planning, with a focus on individual survival, and towards a strategic orientation that is value based (Deshpande et al., 1993) and requires a 'business model' that is rooted in such an externally and value focused view of public services delivery.

A business model is a simplified representation of choices both about how an organisational entity, public or private, creates and distributes value amongst its stakeholders over time and how it ensures its own sustainability into the future (Zott et al 2011). Business models are more than a simple descriptive narrative - they need to guide practical actions (Magretta 2002). Nor are they unchanging recipes since successful business models will evolve with environments and opportunities: New combinations of external needs and possible solutions are constantly emerging and recombining as technology and the environment change (Baden-Fuller \& Morgan 2010)

Traditional business models in the private sector have been predicated upon the 'single bottom line' of organisational profitability as a measure of sustainability. However, as discussed above, this is an insufficient measure of sustainability for PSOs. Public service business models need to be more sophisticated and to be predicated upon public value rather than an organisational 'single bottom line'.

Consequently, our approach moves beyond the narrow focus of traditional business models. Further recent authors have argued strongly that this approach is not 'fit for purpose' for modern businesses, let alone PSOs. Most significantly, Lusch \& Vargo (2014, see also Verma \& Jayasimha 2014) have argued robustly that contemporary business require business models embedded within a service-dominant logic because this logic, predicated upon knowledge transformation, is the basis for value creation for any type of business. This is the approach that has been followed here. What is proposed is a framework within which to develop sustainable business models for a whole range of PSOs. The seven elements of the framework are not constant for all PSOs - the balance between these elements will be different for different PSOs or service scenarios. Moreover the elements do overlap to an extent, 
or approach similar issues from different directions. Consequently this framework has the potential both to steer research and evaluation upon the delivery of public services and to guide public service managers in developing sustainable business models for their own agencies.

\section{Towards sustainable business models for PSOs: the SERVICE framework.}

Thus far we have argued for embracing rather than minimising the complexity that PSOs face in achieving sustainability, as well as for clarifying what this might mean in the context of public service systems. We have argued for a value-based approach that emphasises the relationships, governance and negotiation that is epitomised within NPG rather than the transactional focus of the NPM. At the heart of this is the public service-dominant business logic (XXXX et al 2013), as discussed above. Drawing together the insights from a growing community of scholars that have been exploring these relational and service-oriented aspects of public services delivery, we argue here for seven propositions to underpin a framework for sustainable business models for PSOs in the twenty first century: the SERVICE framework. The use of such heuristics as this have been argued elsewhere to be an essential contribution to effective business process redesign - both as conceptual tools and as guides for enacting theory in practice (Reijars \& Mansar 2005)

Some of these propositions have already been articulated above already, but they bear repetition as part of the whole. These propositions are that

- Public services are systems and not just organisations, or even interorganisational networks, and need to be governed as such, embracing all of their elements (Radnor et al 2014),

- Individual PSOs need to embrace embed_organisational sustainability in their own right in the short term - but this is a necessary and not a sufficient condition for the long term sustainability of PSOs and of public service systems (Boozeman 2002, Grindle \& Hilderbrand 1995),

- Sustainable PSOs are dependent upon building long-term relationships across service systems rather than seeking short term discrete and transactional value (McLaughlin et al 2009, McGuire 2012), 
- Consequently, such internal efficiency is necessary for individual PSOs but will not in isolation produce sustainable public service systems; rather PSOs need to be outward-focused on external effectiveness for service users and on creating sustainable public value for local communities (XXXX 2013, Vidal 2013),

- PSOs need to innovate and negotiate innovation across service systems to achieve service effectiveness (Osborne and Brown, 2011),

- Co-production is at the heart of public services delivery and is the source both of effective performance and of innovation in public services (Osborne \& Strokosch 2013), and

- Public service systems need to develop, capture and use the key resource of knowledge to sustain and delivery effective service experience (Lusch and Vargo 2006, 2014).

Put figure 1 here 
The 'SERVICE' framework for sustainable business models for PSOs

Proposition 1: public services are Systems not just organisations and need to be governed as such. The NPM was predicated upon the necessity of individual PSOs to compete in markets and quasi-markets (Le Grand 2007). This required them to clarify unit costs on a discrete basis and invariably ignored the transaction costs of such a business model - despite long-standing evidence in commercial markets of the impact of such ignorance (e.g. Dyer \& Chu 2003).

Consequently PSOs, like for-profit organisations in the late twentieth century, started to explore the efficacy of inter-organisational networks as an alternative to, or modified form of, the market model (Rhodes 1997, Kickert 1997, Provan \& Milward 2001, Klijn 2008), and in order to develop models of sustainability predicated upon collaborative endeavour rather than competition (Best 1990, Phelps \& Raines 2003).

Whilst such approaches perhaps engaged more with the actuality of public services provision in the post-modern era (Havari 2007), they nonetheless continued to mistake the nature of this provision as being something that was the domain of PSOs individually. However, a core tenet of the New Public Governance and a public service-dominant logic is that PSOs are only part of the systems that delivery public services. Other key elements include service users themselves, their families and significant others, local communities, for-profit and third sector organisations and, hard and soft technologies. Sustainable PSOs must therefore embrace these service systems and learn how they interact with their other elements in order both to be sustainable within these systems and to contribute to sustainable service systems. Technologies for such systemic and process-oriented business models do exist notably service blueprinting (e.g. Shostack 1982, Lovelock \& Wirtz 2006). They have begun to be applied to public services delivery in discrete areas, such as higher education (Baranova et al 2010, Radnor et al 2014). However their potential for contributing to sustainable PSOs and sustainable public services is yet to be fully realised. This service system perspective is the cornerstone of our framework of sustainable business practice for public services. 
Proposition \#2: PSOs need to Embed organisational sustainability in their own right in the short term - this is a necessary but not a sufficient condition for long term sustainability,

As discussed above, a significant contribution of the NPM to public management was to articulate that PSOs have to address the issue of organisational sustainability if they are to continue to contribute to public service systems (and maintain their employment of staff and managers, needless to say). A limitation of this NPM reasoning, though, was then to suppose that such sustainability derived from creating PSOs as individual service 'silos' responsible for their own costs and in rivalrous competition with all other PSOs (McLaughlin et al 2009). However such a model has long been out of favour in successful for-profit service businesses due to, amongst other factors, that fact that it makes the sharing of risk in relation to innovation problematic (Best 1990, Williamson 2000).

As this limitation of the NPM became apparent, in Europe at least, public policy and PSO managers turned to alternative strategies - including inter-organisational networks and social enterprises and entrepreneurship. Whichever alternative is adopted however, a basic element of a framework for sustainable pubic services is to understand that the sustainability of individual PSOs is a precursor (albeit an essential one) to service system sustainability - which must be the ultimate goal. A key contribution of a public service-dominant logic is to argue that organisational and service system sustainability are inextricably linked together. As Normann (2000) points out, service firms can only be successful if they embrace the overall service system, and these service systems themselves require sustainable service firms as one of their essential elements. Bringing propositions \#1 and \#2 together our framework for sustainable public services argues that PSOs need to be simultaneously sustainable in their own right whilst also recognising that service sustainability is only possible when this is embedded within sustainable public service systems. 
Proposition \#3: sustainable PSOs are dependent upon building longterm Relationships across service systems rather than seeking short term transactional value. Given that we have argued in our first two propositions that PSOs cannot operate in isolation of the holistic service systems that they exist within, it follows axiomatically that the governance of relationships within these systems is a key task for their sustainability. One of the failures of public services marketing, as it has evolved over past four decades, has been for it to become situated a tool of the 'marketisation' of public services as part of (often ideological) NPM-style agendas, rather than as a desirable management discipline in its own right (Walsh 1994, Burton 1999) In doing so it has neglected the opportunities offered by alternative conceptualizations of marketing that take institutions and networks, rather than discrete transactions, as the central unit of analysis (Laing 2003). McLaughlin et al (2009) have argued that public services marketing practice has been dominated by precisely such transactional models of marketing and that has belied the relational complexity of public service systems - and have hence contributed to their lack of sustainability. There has also been a consequent failure to explore alternative approaches to marketing that might offer a route to genuine sustainability by identifying and facilitating the enduring relationships that are essential to sustainable public services (Erridge \& Greer 2002, Schwartz 2005, Bovaird, 2006).

The genesis of public services marketed is generally credited to the work of Philip Kotler (inter alia, Kotler \& Levy 1969, Kotler \& Andreason 1975). Crucially, Kotler's ideas about public services marketing were rooted in classical economics and a model of exchange theory that supported a purely transactional view of marketing, with the PSO as a discrete entity operating in isolation from other organizations. This position has been criticized latterly in the broad management literature, through the concepts of the 'new competition' (Best 1990) and 'new institutionalism` (Powell \& DiMaggio 1991). Drawing upon the work of Benson (1975) on resource-dependency theory and Williamson (1985) on transaction cost analysis these approaches posit the need for collaboration in order for PSOs to lever in the information, resources and capabilities necessary for sustainability. Such a model introduces new levels of complexity to exchange relationships that McLaughlin et al (2009) have argued are 
beyond the scope and competencies of traditional transactional models of marketing. The alternative, they contended, is to embrace the service-dominant model of relationship marketing.

Relationship marketing (RM) acknowledges that sustainable competitive advantage increasingly requires collaborative activity rather than rivalrous competition, and that relationships are often the most valuable resource of an organisation, public or private (Payne \& Ballantyne 1993, Veloutsou et al 2002, Helfert et al 2002). Harker (1999) has defined RM as an organization engaging in '...proactively creating, developing, and maintaining committed, interactive and profitable exchanges with selected customers over time'. (p. 16). The core of such relationship building is trust.

Given the enduring emphasis in public policy upon trust as a governance mechanism within the plural state (Davis \& Walker 1997, Osborne 2006), it is surprising therefore that RM has not yet made a significant contribution to public management. It offers a robust framework by which to fashion and guide, and when necessary terminate (Gulati et al 2000), inter-organizational relationships within the plural state.

This contribution is enriched further by allying it with the associated concept of 'relational capital'. Kale et al (2000) define this as '... the level of mutual trust, respect and friendship that arises out of close interaction at the individual level between alliance partners.' (p. 218, our emphasis). The key contribution for PSO managers here is to focus upon the import of individuals and individual relationships. Too often in the public administration and management field, relationships are reified to the organizational level - the neo-corporatist assumptions of the now defunct Voluntary Sector Compact in the UK are a good example of this (Osborne \& McLaughlin et al 2002). A focus on relational capital makes explicit that the key to effective relationship management is to locate them at the individual level, where the staff of a PSO interact with policy makers, the staff of other PSOs and service users. Such an approach is essential to building a sustainable business logic for PSOs. 
Thus far this discussion has emphasised the contribution of RM to enhancing interorganisational trust and relationships. However the approach also speaks to the equally important issue of the relationships between service providers and their uses - denoted 'business-to-customer' (or B2C) relationships within RM (Gummesson 2007). As is discussed further below, the co-production of public services between PSOs and their users is essential to service system sustainability. RM has an important, and to date unrecognised, contribution to make to this debate in public management - and to a framework for sustainable public services.

Proposition \#4: internal efficiency is necessary but not sufficient for sustainable PSOs- they need also to have an outward not inward-facing focus on (Public) Value. This proposition is a corollary of propositions \#1 and \#2 - it explores their implications for managerial practice within PSOs. Perhaps one of the most disappointing failures of the NPM has been that of the application of 'Lean' approaches to reforming and improving public services delivery (Radnor \& Walley 2008). Lean seeks to 'design out' inconsistency and waste in the operational processes of service delivery. It is predicated upon the need to design these processes to produce maximum value for their end-users (Womack \& Jones 1996, Holweg 2007).

In the last decade such approaches have been seen extensively as a panacea for poor public service performance and as a significant contribution of the NPM to their reform. Indeed, their early implementation did lead to substantial improvements in the efficiency of public services delivery in a range of areas including local government, the health service and national government functions (e.g. Barraza et al 2009, Radnor 2010). However, such efficiency gains did not prove to be sustainable in the longer term. There were two reasons for this (Radnor \& Osborne 2013). First these savings came primarily from Lean addressing prior design faults in PSOs rather than addressing longer term sustainability issues. Once these 'low hanging fruit' had gone, though, Lean proved incapable of addressing the more fundamental question of a sustainable business model. Second, and most relevant here, the application of Lean within PSOs mistook the nature of end-user value. It universally 
took an inward-focus upon internal end-users and user value, rather than externally focused on service users and public value ${ }^{1}$. Put simply, such an approach is able to create more efficient PSOs (by improving internal efficiency) but fails to address public service effectiveness because it does not orient itself to public value as expressed by its external end-users or debated within the democratic polity. Such a mistaken approach resulted in very efficient but permanently failing PSOs (Meyer \& Zucker 1989, Jas \& Skelcher 2005) - in the sense that they systemically failed to address the issue of creating public value for end users (Gains \& Stoker 2009). It is essential of course to enhance and make sense of internal efficiency and to address organisational sustainability, as discussed. But this only produces long term sustainability, for PSOs and public service systems, when it is predicated upon an external focus that is about adding value to the external end- users of public services.

\section{Proposition \#5: Sustainability for PSOs is predicated upon Innovation as} means through which to achieve service efficiency and effectiveness. NPM acknowledged innovation as essential to sustainability in public services. However its model was derived from product-dominant approaches to innovation that situated it as a driver for competitive advantage in competitive commercial markets (for example, Porter 1985). Increasingly though, the for-profit sector has come to the view open, collaborative, innovation as a more effective route to commercial sustainability - and particularly in the service sector where multiple service firms can interact within a service system (Bishop et al 2008, Skalen et al 2014). Not only does it share the costs and risks of innovation, it also combines the resources and knowledge of different firms to enhance innovative potential (for example, Chesbrough 2003, Von Hippel 2006).

Once more drawing upon the services management literature, we would argue that for innovation to contribute to sustainable PSOs and public service systems it needs to break free of the product-dominant constraints that have inhibited its contribution to such sustainability in the past (Osborne \& Brown 2011, Djellal et al 2013). There

\footnotetext{
${ }^{1}$ In contrast such an external end-user focus was a core feature of the Toyota Production System that was applied to for-profit businesses, and from which the model of Lean evolved (Holweg 2007).
} 
are three conditions for this. First, as already articulated it needs to be externally focused to add value to the lives of service users rather than focused on internal efficiency (alone) (Chen et al 2014). Second the service user and co-production are required to be at the heart of the process if innovation is to be genuinely oriented to service effectiveness (Skalen et al 2014, Verma \& Jayasimha 2014). Finally, governance rather than management is the essence of innovation in intricate interactive service systems. To take but one example, XXXX (2013) have illustrated how a governance approach to risk is essential to innovation in designing and delivering public services, that requires the negotiation of innovations across such complex service systems and that makes explicit the costs and benefits of any innovation as well as where these might lie (see Kinder 2000 for an example of the impact of the avoidance of such risk governance on innovation in public services).

Innovation is an inherently risky process - the majority of innovations fail as the evidence demonstrates (Klein \& Sorra 1996). If it is to contribute to sustainable business logic for public services then an explicit engagement with these risks and their governance is essential. If such a proactive process is engaged in, innovation offers a real contribution to sustainable PSOs. This can be through their continuous development and improvement (incremental innovation), the development of new services complimentary to those that a PSO currently offers (evolutionary innovation), the geographic or industry-expansion of existing services to new groups of service users (expansionary innovation), and the creation of genuinely new forms of public services that address newly identified needs in novel ways (total innovation) (XXXX 2011).

\section{Proposition \#6: Co-production is the source both of effective performance and} of innovation in public services. As discussed earlier, there is a substantial and growing literature within the public management literature concerned with 'coproduction' in the implementation of public policy and the design and delivery of public services (e.g. Alford 2014, Fledderus et al 2014, Pestoff 2014, Van Eick \& Steen 2014). Whilst this literature includes a continuum of perspectives on coproduction, it has often set the co-production of public services apart as a variation on the 'usual' model of public service delivery where 'public officials are exclusively charged with responsibility for designing and providing services to citizens, who in 
turn only demand, consume and evaluate them' (Pestoff 2006, p. 506; our emphasis). Thus it discusses the ways in which user involvement can be 'added into' the operational process of service delivery (Bovaird 2007).

Such an understanding of co-production, we would argue, is derived from a productdominant logic where production and consumption are separated as discrete processes - thus public services are conceptualized as products to be designed and produced by public policy makers and service professionals and consumed (relatively) passively by service users. Co-production can only occur at the behest of, and controlled by, service professionals. However, a central tenet of the public service-dominant logic is that co-production is an unavoidable element of public services delivery and central to a sustainable business model for PSOs.

We would argue that co-production is an essential and intrinsic process of interaction between any service organization and its service users at the point of delivery of a service (Gummesson 2007). From a public service-dominant approach, therefore, there is no way to avoid the co-production of public services. The question thus is not how to 'add-in' co-production to public services but rather how to actively engage and work with it in order to ensure sustainable PSOs and public service systems (Osborne \& Strokosch 2013). We would also add that co-production does not always have to be a positive process. If its actuality is mishandled it can lead negative effects for external public value and public service effectiveness - as the emergent literature on 'co-destruction' in the services management field has begun to make explicit (Echeverri \& Skalen 2011, see also Needham 2008)

Normann (2000) has encapsulated co-production as 'the moment of truth' of services delivery. Service organisations can only 'promise' a certain process or experience the actuality is dependent upon such co-production. A classic example of this would be the co-produced experience of residential care by the interaction of staff and service users in a residential home for the elderly. The managers of this home may have a vision of what care they want to provide, but the actuality of it is enacted in the iterative interactions between service staff and service users. 
In reality, of course, such co-production of public services is a continuum rather than a steady state. Public services such as residential care and education are clearly instances where it is high, owing to the fact that consumption and production take place at the same point in time and with direct face to face contact between the service user and the service provider (in the care home or the classroom respectively). By contrast, they are rather lower for electronic public services (such as paying your local taxes through a web portal) that do not have the inter-personal immediacy of face-to-face contact between the service provider and the service user.

Conceptualising co-production as a core element of sustainable public services reframes our understanding both of the service delivery process and of the role of public management in achieving such sustainability. To take just one issue, a public service-dominant approach to innovation in public services puts the service user rather than the policy maker or professional at the heart of this process (e.g. Gallouj, 2002) and has profound implications for the management of the process as stated in proposition \#5 - such as in terms of how public service innovations are derived and how risk is governed in the innovation process, as discussed previously.

A core element of a public service-dominant approach to the co-production of innovation also relates to our final proposition \# 7. This is its potential to unlock the tacit or 'sticky' knowledge that service users possess in order to improve existing or develop new services (Von Hippel 1994, 2006). Here, a PSO proactively seeks to uncover, understand and satisfy 'latent (or future) needs', rather than simply reacting to existing or currently expressed needs - as has invariably been the case with public services. This then takes the process beyond co-production alone and unlocks the potential for the co-design and co-creation of public services between service users and service professionals, both increasingly argued as vital for sustainable public services into the future (Bason 2010, Alford 2014). The services management literature has highlighted a range of ways in which such service user co-production of innovation can be achieved (for example, Alam 2006) as well as highlighting some of its drawbacks and dangers (such as over-customisation and its consequent financial implications). It has also explored the way that service users can destroy as well as create value, through 'co-destruction', as noted above. This is a further significant debate that is absent from public management and which could enrich the 
discourse on public services delivery and reform, as well as contributing to sustainable public services for the future.

\section{Proposition \#7: a key resource for PSOs is knowledge and using it for} delivering service experience. Two of the most common truisms about services management are: That service performance is created when service user expectations collide with the reality of their service experience and that the process of service delivery is about the transformation of knowledge into such a service experience (Muller \& Zenker 2001, Gebert et al 2003). This is as true for public services as it is for other services. Despite this, public policy makers and public service managers have persisted in the search for product-design routes to sustainability - through the iterative restructuring of PSOs or through a focus on the technical specification of public services, in terms of professional roles, rather than upon this value-adding knowledge-transformation process.

For public services the sources of such knowledge are threefold - the technical knowledge of public service professionals, the 'sticky knowledge' (Von Hippel 1994) of service users, and the contextual knowledge of other key stakeholders in the public service delivery system (such as carers, family members, and members of the local community). A sustainable business model of PSOs has to focus upon how to capture these varying forms of knowledge, weigh them against each other and transform them into service outcomes for their end users. This task has been made both easier and more complex by the advent of digital technology. This offers the promise of greater access to a wider range of knowledge sources - but such access also offers a challenge in terms of sifting and weighing these information sources against each other (Dunleavy et al 2006).

Elsewhere, Lusch \& Vargo $(2006,2014)$ have argued that such transformation of knowledge is actually the defining feature of a sustainable business model in any market, public or private, product or service based. A sustainable business model is thus not concerned with the control of the unit costs and internal efficiencies of a production process, but rather with 'the application of specialized skills' and where 'knowledge is the fundamental [resource]'. In this process the service user is always the co-producer of value in that there is no extant value for a service until it is used - 
'experience and perception are essential to [service] value determination' Lusch \& Vargo 2006, p. 44). A public service-dominant model of sustainable business practice is thus one that places the utilisation and transformation of knowledge and skills at the heart of public service delivery to achieve service experience rather than the specification of units of output and their associated costs.

\section{Conclusions: towards sustainable PSOs and sustainable public service systems}

This paper has argued for a public service-dominant approach to delivering public services as the only route to long term sustainable PSOs and sustainable public services. It has argued that the NPM, whilst containing important insights and produced some legitimate gains, was a flawed model and has had variable results in implementation (Pollitt 2000). First it sought to impose a product-dominant logic onto public services rather than understanding the fundamental differences between product and services management. Second, it has been unable to come to terms over the last decade with the emerging dominant paradigm of public services delivery - New Public Governance (NPG) (Osborne 2010) which has recognised that public services delivery requires the governance of sophisticated public service systems rather than individual PSOs. As an alternative we have argued for a framework for a sustainable business model for PSOs that embraces their public service-dominant nature. Subsequently we have developed this argument into seven propositions to support a sustainable business model for PSOs and for public service systems. These are shown diagrammatically in Figure 1 in our 'SERVICE' framework for a sustainable business model for public service organisations. This framework now requires further empirical testing to refine its components, test out their limitations and exceptions and to develop metrics to evaluate their impact.

We would close with three areas requiring critical attention. First, our argument has already alluded to the development of ICT and digital technology. As for services in general (Surjadjajaj et al 2003, Ghosh et al 2004), this poses important challenges to sustainable PSOs and sustainable public services, by challenging their very nature. Most public services have traditionally been based upon Normann's 'moment of 
truth' where service providers and service users interact in real-time. Increasingly though such moment of truth are becoming virtual and mediated by digital technology. Work has begun upon exploring the implications of this seismic innovation for public services (for example Margetts 2009). The implications of this work for sustainable PSOs and public services urgently need to be considered.

Second it would be sophistry in the extreme to characterise all public services as part of a homogenous whole. Inevitably there are differences between public services in different service sectors or at different points of the public service delivery chain. Whilst we would argue that the principles of sustainability identified here are germane to all PSOs and public services, their actuality and import will vary. The contingencies of such variation need to be identified and explored to deepen our understanding of truly sustainable public services.

Finally, in addressing the practical challenges of making a reality of public servicedominant sustainability it is not necessary to reinvent the wheel. Key knowledge does exist on such topics as working with stakeholders across public service systems (Bryson 2004, Crosby \& Bryson 2005), upon externally focused strategic planning and management for PSOs (Stone 2010), inter-organisational network governance (Klijn \& Koppenjan 2000), and upon risk governance for public services (Brown \& Osborne 2013). This knowledge requires to be harnessed to underpin an effective approach to a public service-dominant sustainable business model for PSOs and public services for both practice and academia. Research attention can then be focused upon the under-researched and under-theorised topics identified above. This is an essential task for the development of public management theory that is fit for purpose in the twenty-first century. 


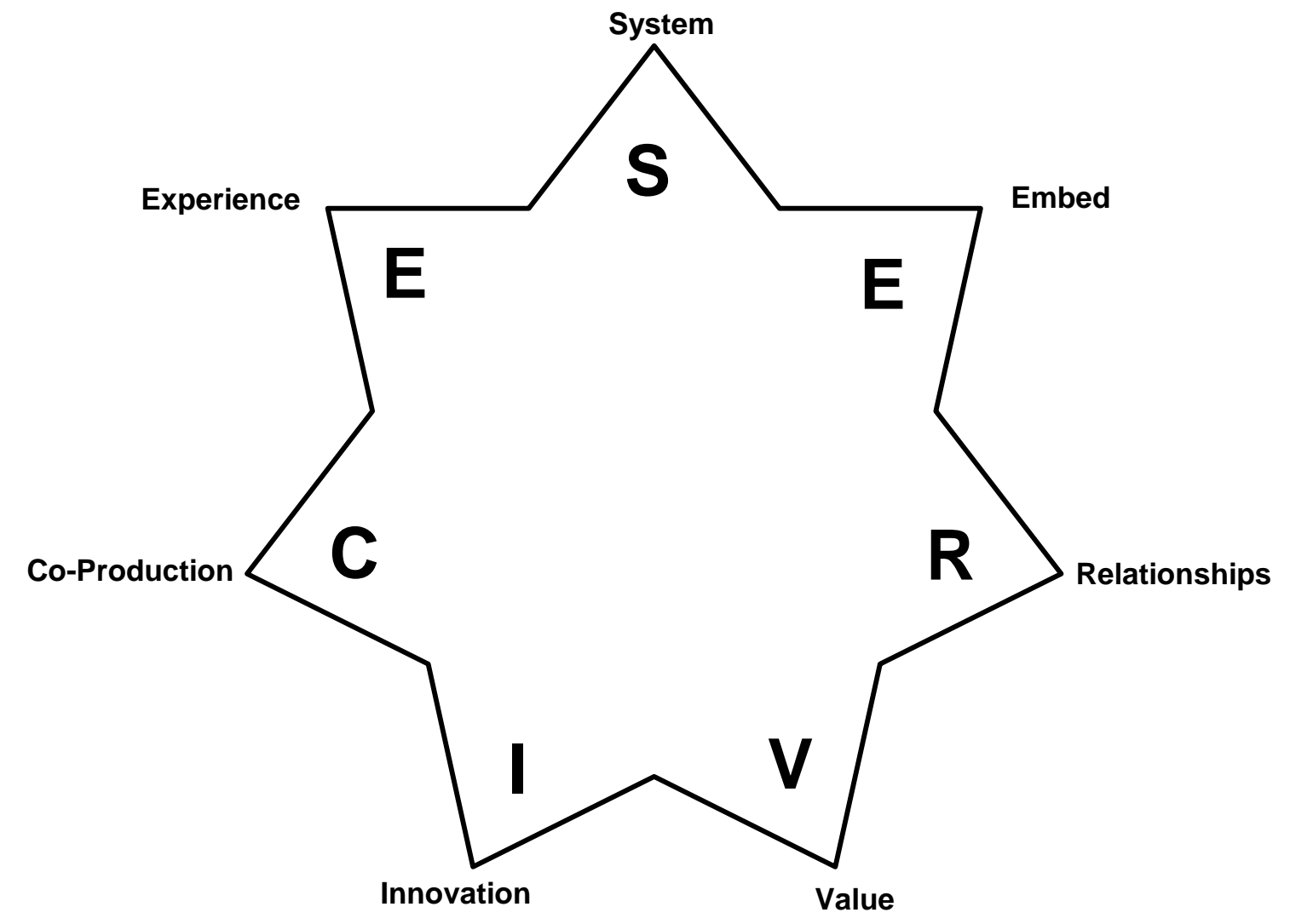

Figure 1: The seven-pointed 'SERVICE' star of a sustainable business model for public services organisations 


\section{References}

Alam, I. (2006). 'Removing the fuzziness from the front-end of service innovations through customer interactions', Industrial Marketing Management, 35, pp. 468-480.

Alford J (2009) Engaging Public Sector Clients: From Service-Delivery to CoProduction (Palgrave Macmillan, London)

Alford, J. (2014). 'The Multiple Facets of Co-Production: Building on the work of Elinor Ostrom', Public Management Review, (16, 3), pp. 299-316.

Ashworth, R., E. Ferlie, G. Hammerschmid, M. Jae Moon, and T. Reay (2013). 'Theorizing Contemporary Public Management: International and Comparative Perspectives', British Journal of Management, (24, Supp. 1) pp. S1-S17.

Baden-Fuller, C. and M. Morgan (2010). 'Business models as models' Long Range Planning, 43, pp. 156-171.

Ball A \& Osborne S (2010) Social Accounting and Public Management (Routledge, London)

Baranova, P., S. Morrison and J. Mutton (2010). 'Service Design in Higher and Further Education: A Briefing Paper', University of Derby, JISC CETIS.

Barraza, M., T. Smith, and S. Mi Dahlgaard-Park (2009). 'Lean-kaizen public service: an empirical approach in Spanish local governments', The TQM Journal, $(21,2)$, pp.143- 167 .

Bason, C (2010) Leading public sector innovation: Co-creating for a better society,

Bristol: Policy Press

Bekkers, V., A. Edwards, R. Moody, and H. Beunders, (2011). 'Caught by surprise? Micro-mobilization. New media and the management of strategic surprises.' Public Management Review, 13, pp. 1003-1022.

Benington, J., and M. Moore, (2010). Public Value: Theory and Practice. Palgrave Macmillan, Basingstoke. 
J Benson (1975) 'The interorganizational network as a political economy' in Administrative Science Quarterly (20) pp. 229-249

Best, M. (1990). The New Competition. Harvard: Harvard University Press.

Bishop K and Associates (2008) Succeeding Through Service Innovation: a Service Perspective for Education, Research, Business and Government (University of Cambridge Institute for Manufacturing, Cambridge)

Boozeman, B. (2002). 'Public-Value Failure: When Efficient Markets May Not Do', Public Administration Review, (62, 2), pp. 145-161.

Bovaird, T. (2006). 'Developing new forms of partnership with the 'market' in the procurement of public services', Public Administration, (84, 1), pp. 81-102.

Bovaird T (2007) 'Beyond engagement and participation: user and community coproduction of public services' in Public Administration Review $(67,5)$ pp. 846-860

Brown, L. and S. Osborne, (2013). 'Innovation and risk in public services: Towards a new theoretical framework', Public Management Review, (15, 2), pp. 186-208

Bryson, J. (2004). 'What to do when stakeholders matter. Stakeholder identification and analysis techniques', Public Management Review, (6, 1), pp. 21-53.

Burton, S. (1999). 'Marketing for public organizations: new ways, new methods' Public Management, $(1,3)$, pp. 373-385.

Chesbrough, H. (2003). Open Innovation: The New Imperative for Creating and Profiting from Technology. Harvard: Harvard Business School Press.

Crosby, B. and Bryson, J. (2005). Leadership for the Common Good. New York: John Wiley. 
Dahler-Larsen P (2014) 'Constitutive Effects of Performance Indicators: Getting beyond unintended consequences' in Public Management Review $(16,7)$ pp. 969986

Davis, H. and B. Walker (1997). 'Trust-based relationships in local government contracting', Public Money \& Management, $(17,4)$, pp. 47-54.

Dawson S \& Dargie C (1999) 'New public management: an assessment and evaluation with special reference to health' in Public Management $(1,4)$ pp. 459-482

Deshpande, R., J.U. Farley and F.E. Webster, Jr. (1993). 'Corporate culture and customer orientation and innovativeness in Japanese firms: a quadrat analysis', Journal of Marketing, $(57,1)$, pp. 23-37.

Djellal, Gallouj F \& Miles I (2013) 'Two decades of research on innovation in services: what place for public services?' in Structural Change and Economic dynamics (27) pp. 98-117

Dunleavy, P., H. Margetts, S. Bastow and J. Tinkler (2006). Digital Era Governance. Oxford: Oxford University Press.

Dyer, J. and W. Chu (2003). 'The Role of Trustworthiness in Reducing Transaction Costs and Improving Performance: Empirical Evidence from the United States, Japan, and Korea', Organization Science, $(14,1)$, pp. 57-68.

Echeverri P \& Skålén P (2014) 'Co-creation and co-destruction: A practice-theory based study of interactive value formation' in Marketing Theory $(11,3)$ pp. 351-373

Elkington, J. (1994). 'Towards the Sustainable Corporation: Win-Win-Win Business Strategies for Sustainable Development', California Management Review, $(36,2)$, pp. 90-100.

Erridge, A. and J. Greer (2002). 'Partnerships and public procurement: building social capital through supply relations', Public Administration, (80, 3), pp. 503-522.

Farris, P, Bendle N ;. Pfeifer P; \&. Reibstein D (2010).Marketing Metrics: The Definitive Guide to Measuring Marketing Performance (Pearson Education, New Jersey) 
Gains F \& Stoker G (2009) 'Delivering 'Public Value': Implications for Accountability and Legitimacy' in Parliamentary Affairs $(62,3)$ pp. 438-455.

Gallouj, F. (2002). Innovation in the Service Economy. Cheltenham: Edward Elgar.

Gebert H, Geib M, Kolbe L \& Brenner W (2007) 'Knowledge-enabled customer relationship management: integrating customer relationship management abnd knowledge management concepts' in Journal of Knowledge Management $(7,5) \mathrm{pp}$. 107-123

Ghosh, S., H. Surjadjaja and J. Antony (2004). 'Optimisation of the determinants of e-service operations', Business Process Management Journal, (10, 6), pp. 616-635.

Gray, R. (2002).'The Social Accounting Project and Accounting Organizations and Society: Privileging Engagement, Imaginings, New Accountings and Pragmatism over Critique?', Accounting Organizations and Society, (27, 7), pp 687-707.

Grindle, M. and Hildebrand M, (1995). 'Building sustainable capacity in the public sector: what can be done?', Public Administration and Development, $(15,5)$, pp. 441-463.

Gronroos, C. (1998). 'Marketing services: the case of a missing product', Journal of Business \& Industrial Marketing, (13,4/5), pp. 322-338

Gronroos, C. (2007). Service management and marketing: Customer management in service competition. Chichester, England: John Wiley.

Gronroos C \& Ojasalo (2004) 'Service productivity: towards a conceptualisation of the transformation of inputs into economic results in services' in Journal of business Research $(57,4)$ pp. 414-423

Gulati, R., N. Nohria and A. Zaheer (2000). 'Strategic networks', in Strategic Management Journal, (21, 3), pp. 203-215.

Gummesson, E. (2007). 'Exit Services Marketing - Enter Service Marketing', Journal of Customer Behaviour, (6,2), pp. 113-141. 
Guthrie, J., A. Ball and F. Farneti (2010). 'Advancing Sustainable Management of Public and Not For Profit Organizations', Public Management Review, $(12,4)$, pp. 449-459.

Harker, M. (1999). 'Relationship Marketing Defined? An Examination of Current Relationship Marketing Definitions', Marketing Intelligence Planning, (17,1), pp. 1320 .

Haveri, A. (2007). 'Complexity in local government change', Public Management Review, (8, 1), pp. 31-46.

Helfert, G., T. Ritter and A. Walter (2002). 'Redefining market orientation', European Journal of Marketing, (36, 9/10), pp. 1119-1139.

Högström C Davoudi S, Löfgren M \& Johnson M (2014) 'Relevant and Preferred Public Service: A study of user experiences and value creation in public transit' in Public Management Review (10.1080/14719037.2014.957343)

Holweg, M. (2007). 'The genealogy of lean production.' Journal of Operations Management, 25, pp. 420-437.

Jas, P. and Skelcher, C. (2005). 'Performance Decline and Turnaround in Public Organizations: A Theoretical and Empirical Analysis', British Journal of Management, 16, pp 195-210.

Kale, P., H. Singh and H. Perlmutter (2000). 'Learning and protection of proprietary assets in strategic alliances', Strategic Management Journal, (21, 3), pp. 217-237.

Kickert, W. (1997). 'Public governance in the Netherlands: An alternative to AngloAmerican "managerialism"', Public Administration, $(75,4)$, pp.731-752.

Kinder, T. (2000). 'A sociotechnical approach to the innovation of a network technology in the public sector', European Journal of Innovation Management, $(3,2)$ pp. $72-90$. 
Klein, K. and J. Sorra (1996). 'The Challenge of Innovation Implementation', Academy of Management Review, (21, 4), pp. 1055-1080.

Klijn, E.H. (2008). 'Governance and Governance Networks in Europe. An assessment of ten years of research on the theme', Public Management Review, $(10,4)$, pp. $505-525$.

Klijn, E.H. and J. Koppenjan (2000). 'Public management and policy networks: Foundations of a network approach to governance', Public Management, $(2,1)$, pp. 135-158.

Kotler, P. and A. Andreason (1975). Strategic marketing for non-profit organizations. Englewood Cliffs: Prentice Hall.

Kotler, P. and S.J. Levy (1969). 'Broadening the concept of marketing', Journal of Marketing, 33,.

Laing, A. (2003). 'Marketing in the public sector: toward a typology of public services', Marketing Theory, (3.4), pp.427-445.

Le Grand, J. (2007). The Other Invisible Hand: Delivering Public Services through Choice and Competition. Princton: Princeton University Press.

Lovelock, C. and J. Wirtz (2006). Services Marketing: People, Technology, Strategy. New Jersey: Prentice Hall.

Lusch, R. and S. Vargo (Eds.). (2006). The service dominant logic of marketing. New York: M E Sharpe.

Lusch, R. and S. Vargo (2014). Service Dominant Logic. Cambridge: Cambridge University Press.

Margetts, H. (2009). 'The Internet and public policy', Policy and Internet, 1, pp.1-21.

Magretta, J. (2002). 'Why Business Models Matter', Harvard Business Review, $(80,5)$, pp. 86-92. 
Meyer, M. and L. Zucker (1989). Permanently failing organizations. New York: Sage Publications.

McGuire, L. (2012). 'Slippery concepts in context. Relationship marketing and public services', Public Management Review, (14, 4), pp. 541-555.

McLaughlin, K., S. Osborne, and C. Chew (2009). 'Developing the marketing function in U.K. public service organizations: The contribution of theory and practice.', Public Money \& Management, $(29,1)$, pp. 35-42.

McLaughlin, K., S. Osborne and E. Ferlie (2002). New Public Management: Current Trends and Future Prospects. London: Routledge.

H Brinton Milward \& K Provan (2000) 'Governing the hollow state' in Journal of Public Administration; Research and Theory $(10,2)$ pp. 359-379

Moore, M. (2002). Creating Public Value: Strategic Management in Government. Boston: Harvard University Press.

Muller E \& Zenker A (2001) 'Business services as actors of knowledge transformation: the role of KIBS in regional and national innovation systems' in Research Policy $(30,9)$ pp. 1501-1516

Normann, R. (2000). Service management: strategy and leadership in service business. New York: Wiley.

Osborne, S. (2006). 'The New Public Governance?', Public Management Review, (8, 3), pp 377-388.

Osborne, S. (2010). The New Public Governance? London: Routledge.

Osborne, S. and L. Brown (2011). 'Innovation, public policy and public services: the word that would be king?', Public Administration, $(89,4)$, pp. 1335-1350.

Osborne, S. and K. McLaughlin (2002). 'Trends and issues in the implementation of local 'Voluntary Sector Compacts` in England', Public Money and Management, (22) pp. 55-64 
Osborne, S., Z. Radnor and G. Nasi (2013). 'A new theory for public services management? Towards a (public) service-dominant approach', American Review of Public Administration, (43, 2), pp. 135-158.

Osborne, S., Z. Radnor, I. Vidal and T. Kinder (2014). 'A sustainable business model for public service organisations', Public Management Review, (16, 2), pp. 165-172.

Osborne, S. and K. Strokosch (2013). 'It takes two to tango? Understanding the coproduction of public services by integrating the services management and public administration perspectives', British Journal of Management, (24, S1), pp S31 - S47.

M Payne, \& D Ballantyne, (1993), Relationship Marketing: Bringing Quality, Customer Service and Marketing Together, (Butterworth-Heinemann, Oxford)

Pestoff, V. (2006). 'Citizens and co-production of welfare services', Public Management Review, $(8,4)$, pp. 503-519.

Phelps, N. and P. Raines (2003). 'The New Competition for Inward Investment', Cheltenham: Edward Elgar.

Porter, M. (1985). Competitive Advantage. New York: Free Press.

Powell, W. and P. DiMaggio (1991). The New Institutionalism in Organizational Analysis. Chicago: University of Chicago Press.

Powell, M., I. Greener, I. Szmigin, S. Doheny and N. Mills (2010). 'Broadening the focus of public service consumerism', Public Management Review, (12, 3), pp. 323340 .

Provan, K. and H. Brinton Milward (2001). 'Do Networks Really Work? A Framework for Evaluating Public-Sector Organizational Networks', Public Administration Review, $(61,4)$, pp. 414-423

Radnor, Z. (2010). Review of Business Process Improvement Methodologies in Public Services. London: Advanced Institute of Management. 
Radnor Z (2007) 'Historical analysis of performance measurement and management in operatrions management' in International journal of Productivity and Performance Management $(56,5 / 6)$ pp. 384-396

Radnor, Z. and P. Walley (2008). 'Learning to Walk Before We Try to Run: Adapting Lean for the Public Sector.' Public Money and Management, 28(1), pp.13-20.

Radnor, Z. and S. Osborne (2013). 'Lean: a failed theory for public services?', Public Management Review, (15, 2), pp. 265-287.

Radnor, Z., S. Osborne, T. Kinder and J. Mutton (2014). 'Operationalizing CoProduction in Public Services Delivery: The contribution of Service Blueprinting', Public Management Review, (16, 3), pp 402-423.

Reijars H \& Mansar S (2005) 'Best practices in business process reengineering: an overview and qualitative evaluation of successful redesign heuristics' in Omega (33) pp. 283-306

Rhodes, R. (1997). Understanding Governance: Policy Networks, Governance, Reflexivity and Accountability. Buckingham: Open University Press.

Rhodes R (1994) 'The Hollowing out of the State' in Political Quarterly $(65,2)$ pp. 138-151

Schwartz, R. (2005). 'The contracting quandary: managing local authority - VNPO relations', Local Government Studies, $(31,1)$, pp. 69-83.

Shostack, G.L. (1982). 'How to Design a Service', European Journal of Marketing, $(16,1)$, pp.49-63.

Skalen P, Gummerus J, von Koskull C, \& Magnusson P (2014) 'Exploring value propositions and service innovation: a service-dominant logic study' in Journal of the Academy of Marketing Science [in press]

Sorin D \& Pollitt C (2014): 'NPM Can Work: An optimistic review of the impact of New Public Management reforms in central and eastern Europe' in Public Management Review, (10.1080/14719037.2014.908662) 
Stoker G (2006) 'Public Value Management: A New Narrative for Networked Governance?' in American Review of Public Administration (36); pp. 41-57

Stone, M. (2010). 'Toward a more and less heroic view of strategic management', Public Administration Review, Vol. 70 (supplement 1), pp. S215-217.

Surjadjaja, H., S. Gosh and F. Anthony (2003). 'Determinants and assessing the determinants of e-service operations', Managing Service Quality, $(13,1)$, pp. 39-53.

Veloutsou, C., M. Saren and N. Tzokas (2002). 'Relationship marketing: what if...?', European Journal of Marketing, $(36,4)$, pp. 433-449.

Verma R \& Jayashima K (2014) 'Service delivery innovation asrchitecture: an empirical study of the antecedents and outcomes' in IIMB Management Review (26, 2) pp. $105-121$

Vidal, I (2013). 'Governance of Social Enterprises as producers of public services' in (eds) P. Valkama, S.J. Bailey and A-V. Anttiroiko. Organisational innovation in public services: Forms and Governance. Basingstoke: Palgrave.

Von Hippel, E. (1994). 'Sticky information and the locus of problem solving: implications for innovation', Management Science, (40, 4), pp. 429-439.

Von Hippel, E. (2006). Democratizing Innovation. Cambridge: MIT Press.

Walsh, K. (1994). 'Marketing and public sector management', European Journal of Marketing, (28,3), pp. 63-71.

O Williamson (1985) The Economic Institutions of Capitalism: Firms, Markets, Relational Contracting. (Free Press, New York)

Wistow, G., M. Knapp, B. Hardy and C. Allen (1994). Social Care in a Mixed Economy. Buckingham: Open University Press.

Womack, J. and D. Jones (1996). 'Lean Thinking: Banish the Waste and Create wealth in your organisation', New York: Simon and Schuster. 
Xue, M. and P. Harker (2003). Service Co-Production, Customer Efficiency and Market Competition. Pennsylvania: Wharton Business School Working Paper 03-03.

Zott, C., R. Amit and L. Massa (2011). 'The Business Model: Recent Developments and Future Research', Journal of Management, (37,4), pp. 1019-1042. 